\title{
ЛІТЕРАТУРОЗНАВСТВО
}

\section{СВОС / ЧУЖЕ: ПРОБЛЕМА ОКРЕСЛЕННЯ ІДЕНТИЧНОСТІ В ПРОЗІ НАТАЛІ КОБРИНСЬКОЇ}

\author{
ІРИНА БОРИСЮК \\ Національний університет „Києво-Могилянська академія”, Київ - Україна \\ borir77@gmail.com; ORCID: 0000-0002-9812-7178
}

\section{SWOJE / OBCE: KWESTIA OKREŚLENIA TOŻSAMOŚCI W PROZIE NATALII KOBRYNSKIEJ}

\author{
IRYNA BORYSIUK \\ Uniwersytet Narodowy „Akademia Kijowsko-Mohylańska”, Kijów — Ukraina
}

STRESZCZENIE. Aktualność artykułu uwarunkowana jest potrzebą reinterpretacji twórczości Natalii Kobrynskiej, jej miejsca w kanonie piśmiennictwa ukraińskiego. Z jednej strony twórcze poszukiwania pisarki odzwierciedlają drogę, którą przemierzała literatura ukraińska na przełomie wieków (tendencje realistyczne i modernistyczne), z drugiej zaś - zawierają one tematy i zagadnienia znacznie wykraczające poza ówczesne ramy czasowe (postać Innego, konstruowanie tożsamości za pomocą dyskursu władzy, wspólne oddziaływanie władzy i wiedzy, impulsy ekologiczne itp.). Kierunek, w ramach którego zrealizowano badanie, wyznaczony jest przez studia poświęcone zagadnieniu tożsamości; w centrum uwagi obecne jest napięcie pomiędzy modusami konstruowania a wyboru. Celem badania jest zatem dowiedzenie, iż w przypadku bohaterów Kobrynskiej tożsamość wiąże się raczej z wyborem aniżeli z przynależnością do wspólnoty. Rezultatem badania jest potwierdzenie, iż, pomimo niestabilności ludzkich wyobrażeń o własnym „Ja”, Natalia Kobrynska odnajduje najbardziej odpowiedni sposób, aby ukazać członków wspólnoty w momencie rozpadu tradycyjnych związków społecznych i kształtowania się nowych.

Słowa kluczowe: Natalia Kobrynska, tożsamość, subiektywność, swoje / obce. 


\title{
THE SELF / THE STRANGER: THE PROBLEM OF IDENTITY OUTLINING IN THE PROSE OF NATALIA KOBRYNSKA
}

\author{
IRYNA BORYSIUK \\ National University of Kyiv-Mohyla Academy, Kyiv — Ukraine
}

\begin{abstract}
The relevance of the article stems from the demand for rethinking Natalia Kobrynska's prose and therefore her position in the Ukrainian literary canon. On the one hand, Kobrynska's artistic searches reflect the development path of fin de siècle Ukrainian literature (realistic and modernist writing). On the other hand, some issues and themes in Kobrynska's prose are actually ahead of her time (conceptualizing the Other, identity construction through power discourses, interrelation of power and knowledge, Kobrynska`s writing ecological impulses and so on). The paper was written within the framework of identity studies; the key issue is the tension between a construction and a choice. The aim of the paper is to demonstrate that Kobrynska's characters' identity is the result of their choices rather than their belonging to society. To conclude, Kobrynska has discovered the most appropriate ways of representation of society's members at the time in which social relations collapse and emergence.
\end{abstract}

Keywords: Natalia Kobrynska, identity, subjectivity, the self / the stranger.

$\Pi$

роблематизація ідентичності, як правило, має місце тоді, коли гомогенність спільноти ставиться під сумнів. На думку видатного культуролога Кобени Мерсера, “ідентичність стає проблемою тільки тоді, коли вона перебуває в стані кризи, коли те, що мислилося фіксованим, цілісним і стабільним, витісняється досвідом сумніву і непевності” [Hall 1992: 597]. Саме так можна описати соціокультурну ситуацію в Галичині останньої третини XIX ст. — національно-культурне відродження відбувається одночасно $з$ поширенням соціалістичних ідей та появою рухів жіночої солідарності. В процесі окреслення ідентичності національний, соціальний та гендерний чинники вступають у взаємодію, утворюють ієрархії, змагаються в значущості. Як зазначає Віра Агеєва, не менш важливим фактором є поширення позитивістських, атеїстичних ідей, що дозволяють 3 антирелігійних позицій переосмислити засади патріархальної культури [Агеєва 2003: 161]. На перший план виступає проблема вибору, пов'язана з усвідомленням і визнанням індивідом своєї суб'єктності - адже тільки той, хто є видимим у простоpi соціальної взаємодії, здатен цей вибір здійснити. Цей аспект критично важливий для Наталі Кобринської - в її прозі конструювання ідентичності тісно пов'язане з проблемами рефлексії й самоусвідомлення: визнаючи свою суб'єктність, протагоніст порушує рівновагу між публічним і приватним, ставить під сумнів усталені культурні уявлення та соціальні стосунки. Це в ідеалі. 
Але найчастіше Н. Кобринська як майстриня тонких нюансів і неочевидних психологічних мотивацій зображує інших героїв - тих, хто перебуває в ілюзії відсутності вибору, хто не усвідомлює себе суб'єктом дії. Таким чином, позбавляючи вибору своїх героїв, вона залишає його за читачами.

Проблематизацію суб'єкта пов'язують із філософією Просвітництва. Декартове твердження “Я мислю, отже, існую” добре ілюструє тезу про автономність людської особистості; крім того, воно $є$ наріжним каменем гуманізму як світогляду, що базується на відділенні суб'єкта від об'єкта — який, у свою чергу, мислиться або як реальність, або як інший суб'єкт. Індивідуальне, автономне Я є суб'єктом, а не є об'єктом дії священної волі або космічних сил - це означає, що автономна людська свідомість трактується не як продукт, а як джерело дії та значення [Ashkroft, Griffiths \& Tiffin 2007: 202]. Таке тлумачення суб'єкта було винятково ессенціалістським - внутрішнє ядро особистості, пов'язане з розумом, свідомістю та дією, мислилося як неперервне, тотожне собі, принципово незмінне протягом життя [Hall 1992: 597]. Проте картезіанський індивідуалізм схильний недооцінювати або ігнорувати роль соціальних стосунків або мови у формуванні Я. Дебати щодо суб'єкт-об'єктних стосунків тривали в європейській філософії протягом усього XIX ст., а критика суб'єктоцентричної концепції досягла кульмінації у філософії Ніцше. Проте найбільш значний поворот, зумовлений відходом від позиції Просвітництва, пов'язують з іменами Фройда і Маркса [Ashkroft, Griffiths \& Tiffin 2007: 202]. Фройдова теорія про несвідомі виміри Я показала, що існують не охоплені думкою аспекти структури особистості — це, в свою чергу, сприяло розмиванню межі між суб' єктом і об’єктом. Маркс, наполягаючи на впливові економічної структури суспільства на життя робітників, проголосив свою знамениту максиму про залежність свідомості людини від соціального буття. Теоретичні роздуми цих двох мислителів захитали ідею про автономність і цілісність людської особистості [Ashkroft, Griffiths \& Tiffin 2007: 202]. Ще раніше вплив соціальних чинників на становлення людини став об'єктом пильної зацікавленості для письменників-реалістів, а залежність людини від неусвідомлених мотивів та імпульсів було відбито в текстах письменників-натуралістів.

Зміну в трактуванні суб'єктності та ідентичності Стюарт Голл пояснює дедалі більшим зростанням складності модерного світу — поступово з'являється усвідомлення того, що внутрішнє ядро суб'єкта не є автономним та самодостатнім, а формується в стосунку до “значущих інших”, що опосередковують для суб'єкта цінності, значення та символи тієї культури, до якої він належний [Hall 1992: 597]. У відповідності з класичною соціологічною концепцією ідентичність формується як взаємодія між самістю і соціумом. Так, суб'єкт все ще осмислюється як наділений внутрішнім ядром (“справжнє Я”), проте це ядро формується й видозмінюється в постійному діалозі із зовніш- 
нім світом - різноманітними культурними світами й тими ідентичностями, що їх вони пропонують [Hall 1992: 597]. Таким чином, ідентичність покриває розрив між зовнішнім і внутрішнім, приватним і публічним. Суб'єкт не тільки проектує себе в певну культурну ідентичність, а й інтерналізує, привласнює їі значення та цінності - в такий спосіб суб'єктивність почуттів співвідноситься з об'єктивністю місця, що його посідає суб'єкт в соціальному та культурному плані. Отже, ідентичність - це механізм вшивання суб'єкта в структуру [Hall 1992: 598]. Радикалізація критики автономності суб'єкта посилюється у філософській думці XX ст. й набуває логічного завершення в ідеях про те, що суб'єкт постає внаслідок впливу ідеології, мови чи дискурсу. Відповідно до теорії Луї Альтюссера, суб'єкти народжуються в ідеології, віднаходять свою суб'єктивність в межах очікувань, нав'язаних батьками і суспільством, i схвалюють їі, оскільки вона формує в індивіда відчуття ідентичності та безпеки завдяки таким структурам, як мова, соціальні коди і домовленості. Отже, суб'єкти діють у змові ідеологією, дозволяючи ій продукувати соціальні значення [Ashkroft, Griffiths \& Tiffin 2007: 203]. Своєю чергою Жак Лакан деконструює ліберально-гуманістичне уявлення про цілісну особистість і неповторну індивідуальність, а також ідею суб'єкта як стійкої амальгами свідомості. На думку Лакана, Я екс-центричне щодо себе: справжня індивідуальність міститься в несвідомому, адже Я постає як продукт мови, а не окрема сутність. Несвідоме є стрижнем нашого буття, але воно подібне до мови, що існує як структура ще до того, як індивід опанує iii [Ashkroft, Griffiths \& Tiffin 2007: 204]. Конструювання суб'єктності в межах певних історичних, соціальних і культурних систем знання в суспільстві було докладно описано Мішелем Фуко. Так, в теорії Фуко дискурс продукує суб'єкта — тобто, суб'єкт залежить від правил тих систем знання, в межах яких він постає. У цьому сенсі дискурс значно ширший і різноманітніший за будь-яку мову чи ідеологію - різні суб'єкти продукуються різними дискурсами, проте процеси продукування за великим рахунком однакові [Ashkroft, Griffiths \& Tiffin 2007: 205].

3 огляду на сказане вище проблематизація ідентичності пов'язана з двома важливими модусами - конструюванням і вибором. Якщо суб'єкт конструюється ідеологією, мовою чи дискурсом, це автоматично впосаджує розмову про суб'єктність в рамки детермінізму - а значить, ставить під сумнів свободу вибору. Одним із перших на цей факт звернув увагу теоретик постколоніальних студій Франц Фанон, коли порушив питання про саму можливість опору колонізованих націй. Соціальна обумовленість суб' єктності потрапляє в фокус уваги дослідників національної та культурної ідентичності: так, Ентоні Сміт визначає національну ідентичність як продукт безперервної репродукції та реінтерпретації зразків цінностей, символів, пам'яті, міфів і традицій, що складають національну спадщину, а також ідентифікацію індивідів із 
цими зразками та спадщиною [Smith 2008: 34]. Натомість сучасне розуміння ідентичності, що його низка дослідників пов'язують із постанням так званого постмодерного суб'єкта, більше обумовлене ситуативним вибором, визначенням ієрархії ідентичностей, а також такими характеристиками суб'єкта, як фрагментарність, перервність і нестабільність. Суб' єкт, що раніше почувався наділеним стабільною та уніфікованою ідентичністю, тепер стає фрагментованим, складеним із кількох, подеколи різноспрямованих чи суперечливих ідентичностей. Внаслідок структурних та інституційних змін ідентичності, що утворювали зовнішні соціальні ландшафти і забезпечували суб' єктивне підпорядкування індивідів об'єктивним потребам культури, виявляються розірваними. Сам процес ідентифікації, внаслідок якого ми проектуємо себе в межі наших культурних ідентичностей, стає відкритим, варіативним та проблематичним. Внаслідок цього суб'єкт в різні періоди часу набуває різних ідентичностей [Hall 1992: 598]. Зигмунт Бауман стверджував, що ідентичність $\epsilon$ чимось радше винайденим, ніж віднайденим - метою докладання зусиль, тим, що має бути збудовано, вибором із альтернативних пропозицій [Bauman 2004: 16]. Леонідас Донскіс наполягає, що модерна ідентичність не так успадкована, як свідомо і вільно сконструйована [Donskis 2009: 6]. Тобто, в межах цих концепцій ідентичність постає наслідком вільного вибору суб'єкта, а не впливу на нього.

У прозі Н. Кобринської ми можемо спостерігати процес змагання ідентичностей, унаслідок яких окреслюється нова соціальна реальність (Виборець) або стає очевидною неспроможність усталеної системи цінностей і поглядів (Дух часу, Катруся і Ядзя, Задля кусника хліба, Янова тощо). Зіштовхуючи в єдиному соціальному полі різноспрямовані ідентичності (національну, культурну, соціальну, гендерну), Наталя Кобринська показує, як зміщуються і змінюються лінії поділу на своє і чуже, а також акцентує на неочевидності таких зміщень, що подеколи визначаються впливом моральних, а не національних, політичних чи соціальних чинників.

Питання ідентичності як свідомого вибору є для Н. Кобринської одним із найважливіших. Оповідання Виборещь є в цьому сенсі текстом, що й дотепер не втратив актуальності. Набуття ідентичності тут осмислюється як процес і свідомий вибір, а не як автоматичне ототожнення себе зі своєю спільнотою - яка, до речі, і так не є засаднично гомогенною. Що цікаво, цей процес відбувається як поступове розширення меж свого простору і перехід від сфери приватного до сфери публічного - проте приватне / публічне співвідноситься тут не 3 жіночим / чоловічим, а з селянським / інтелігентським (а також панським). Вибір селянина Якима Мачука стосується не тільки того, за кого йому голосувати, а також того, ким йому бути. Вельми показово, що на початку оповідання усвідомлення того, чим є свій простір, обмежується для Якима хатою і городом. Своє - це передусім власний грунт, відвойована 
у природи орна земля: Всі вони разом були як би одною силою, одною мочею, щзо йшла проти другої сили і мочі, спочиваючої в землі, котру поборювали лиш маленькими частинами, краючи скибу за скибою [Кобринська 1990: 98]. Проте Якимове роздратування через те, що доведеться за виборами згаяти погожу днину, змінюється роздумами про причини відчуження власної праці: Уже видко, таке боже право, що хто хоче жити, мусить на себе робити! Чому ж так не іде межи людьми? [Кобринська 1990: 100]. Н. Кобринська з неабиякою майстерністю показує зміни, пов'язані з усвідомленням людиною власної суб'єктності. В цьому сенсі вельми промовистим $€$ те, що Яким стає кандидатом у виборці не зі своєї волі, а тому, що йому випадає жеребок. Пізніше, коли селяни голосують за нього, він уже вболіває за те, щоб таки стати виборцем. Збережене в середовищі традиційної культури уявлення про детермінізм людського життя руйнується усвідомленням можливості вільного вибору — доля поступається місцем волі. Усвідомлення своєї суб'єктності породжує відповідальність за вибір, що його має бути зроблено правильно, але саме рішення не $є$ для Якима легким. На це звертає увагу Микола Легкий: „На передній план таким способом виведено процес формування національно свідомого українського селянства; процес, котрий тільки-но починається, адже в вендепункті твору запах землі - «запах мужицької кервавиці й поту» — викликає в селянина сумнів, чи обраний «пан зі Львова обітре той кервавий піт з мужицького чола, чи зменшить податки і дачки, чи верне право до затраченої землі». «Не знати!.. » — врешті-решт констатував Яким" [Легкий 2012: 100].

Цей вибір зумовлений для Якима не тільки моральними настановами, а й питанням ідентичності. Що цікаво, письменниця наголошує саме на проблемі конструювання ідентичності, що іï можна вважати радше наслідком, ніж причиною впливу таких факторів, як ідеологія, дискурс і мова [Ashkroft, Griffiths \& Tiffin 2007: 201-207]. В оповіданні йдеться про дві кандидатури пана зі Львова і пана з Ківковець. Кандидатуру першого обстоює сільський священик, кандидатуру другого - війт. Для священика важливим $є$ вибір національної ідентичності, тому він радить голосувати за "руського посла": Якби русини всі разом трималися, то поляки би тоді пізнали: „Чия хата, того правда, i сила, i воля" [Кобринська 1990: 101]. Як пояснювала ситуацію сама Н. Кобринська, „... тім хаосі видний був один напрям - не датися полякам! В краєвім соймі велася з ними роз'ярена боротьба о народні права, та ще більше розлючена велася газетярська полеміка" [Кобринська 1980: 311]. другого боку, війт апелює до соціальної ідентичності Якима: Пан зі Львова чи пан із Ківковець - скажіть самі, чи це не все одно? Пан паном, а мужик мужиком! Від панської ради мужикові легше не буде! [Кобринська 1990: 113]. I священик, і війт посилаються на соціальні кривди селянства, проте по-різному формують образ винного-чужого: для священика це здирники-поляки, для війта це здирники-пани. Обидва аргументи є для Якима досить пере- 
конливими, проте в кінцевому підсумку зовсім не вони впливають на його вибір. Яким вагається до останнього, в дорогу до міста вирушає сам. Власне, лише в дорозі, яка сама по собі є наочною метафорою постання суб'єкта, він робить остаточний вибір. На в'їзді в місто єврей-шинкар пропонує готель і їжу задурно, аби було зроблено “правильний” вибір на користь ківковецького пана, натомість Никольця, священичого сина, арештовують за політично небезпечні промови.

Тому вирішальний вибір Якима грунтується не на раціональному зважуванні аргументів, а на моральних роздумах, що випливають із невисловленого запитання про те, чим людина здатна пожертвувати заради своїх переконань: .. Скажи сам, чоловіче - якби ти мав за собою право, чи треба би тобі свідків підкуплювати? [Кобринська 1990: 120]. Важливим є те, що Якимів вибір $є$ вибором моральної дії - він найменше зважає на такі аргументи, як загальне добро, і цілком усвідомлює обмеженість свого знання в ситуації політичних суперечок. Але він не хоче бути “збаламученим, підплаченим негідником": тобто, з непомильною точністю він приймає рішення в межах власної компетенції — не як вибір на користь найбільш прийнятної кандидатури, а як вибір на користь моральної поведінки. Саме такий аргумент цілком зрозумілий Якимисі, яка на виборах знається ще менше за Якима і плутає виборця з війтом і збирачем податків. То недобрі були гроші [Кобринська 1990: 123] — каже Яким дружині, що вже подумки витратила дану війтом десятку, і вона відступається. Вельми промовистим $€$ те, в яких категоріях сільська традиційна культура осмислює покарання за аморальні вчинки. Ідеться не про правову (злочин) і не про християнську (гріх), а про міфологічну категорію шкоди. Як зазначає М. Новикова, „богословські та моральні поняття Добра і Зла означилися в людській культурі не одразу. Довгий час їх замінювали набагато “утилітарніші” та “операційніші” поняття Користі та Шкоди” [Новикова 1993: 23]. В основі такого світогляду лежить міфологічне уявлення про світ як місце, де блага $є$ скінченними. Доля - не тільки визначений від народження приділ, а й частка цього світового блага; взяти більше за належне — це позбутися того, що тобі від роду судилося: Злих грошей вона не хотіла. Кажуть, щзо крадене вдесятеро відпаде, а злий гріх міг би звести на нінащо і иіле таздівство [Кобринська 1990: 123].

Цікаво, що з розширенням меж “свого” простору розширюється і Якимова самосвідомість: Та не лиш єго ім'я виринуло з тихого закутка, але в єго душі вийшла така сама зміна: він ніби прочув, провидів [Кобринська 1990: 125]. Згадка його імені в газеті - одним із перших серед тих, хто виступав проти зловживань - прямо і безпосередньо виводить Якима з приватного простору в публічний. Усвідомлення суб'єктності відбувається з огляду на іншого Яким постає як моральний суб' єкт передусім в очах іншої людини (Про него пишуть, говорять, хвалять єго за чесний і добрий поступок! [Кобринська 
1990: 124]). Змінюються також межі свого і чужого: землю Яким осмислює вже не як грунт, а як простір (“одна велика руська земля”).

Не менш важливою є напруга між своїм і чужим у воєнних новелах Н. Кобринської, адже чужий не завжди означає ворога, а ворог не конче може бути чужим. Радше, лінія поділу проходить між військовим і цивільним світами. Цікаво, що письменниця оминає теми героїзму, колективного піднесення чи волі до перемоги. Війна тут показана не з точки зору спільноти — як масштабні колективні рушення чи згуртованість під час небезпеки, - а з точки зору окремої людини, підхопленої виром подій і не здатної впливати на ситуацію, не надто схильної до саморефлексії, розчавленої емоціями, з якими вона подеколи не має сили впоратися. На відміну від своїх героїв, сама Н. Кобринська до останнього переймалася суспільними справами. Ірена Книш у своїй розлогій монографії зазначає, що письменниця була активною діячкою жіночого комітету для допомоги Українському Червоному Хрестові [Книш 1957: 292]. Війна — це стихія, що несе смерть, подібна до страшної природної стихії у повісті Ядзя і Катруся чи оповіданні Хмарниия. У фокусі уваги письменниці - не герої, а жертви, причому не тільки цивільні, а всі, хто втрачає суб' єктність і опиняється на маргінесі через військові дії. Це дівчина, що чекає коханого з війська (Свічка горить), поранений і полишений своїми жовнір (Полишений), матір із дітьми й каліка, що повернувся з війни (Калі$\kappa a)$, загиблі, над могилами яких триває життя (Ha цвинтарi) і навіть кінь, що втратив вершника (Кінь).

У воєнних новелах Н. Кобринська розмірковує про природу насильства, причому не тільки фізичного. Убивці ії героїв - не конкретний персоналізований ворог, а сліпа анонімна сила. Так, від повітряного обстрілу гине Маланка $з$ оповідання Каліка, а безіменний “неприятель” вбиває улана з новели Кінь. Проте ще страшнішим є насильство деперсоналізованої, розсіяної, втіленої в конкретиці інституцій, а не людей, влади. Ця втілена в соціальних інституціях влада не тільки формує межі суспільного простору і публічної взаємодії, а й чинить вплив на сферу приватного. У новелі Свічка горить мобілізація до війська ії коханого стає для Марти страшним ударом, проте відсутність листів від нього ії просто приголомшує. Одного дня до Марти приходить кілька незнайомих чоловіків, і таємниця розкривається. Виявляється, військова поліція не пропускає iї листи, адже сприймає їх як зашифровані повідомлення: в кожному листі дівчини повторюється та сама фраза - Свічка горить день $i$ ніч [Кобринська 1990: 310]. Це виявляється для дівчини найстрашнішим ударом: Все, щзо скривалось на дні ї̈ душі, витягнули люди на прилюдний вид, обкинули поблажливим усміхом легковажаня найдорожчий ї̈ скарб, найціннішу суть ї̈ існування [Кобринська 1990: 310]. 3 дивовижною проникливістю і глибиною Н. Кобринська в художньому тексті передчуває сформульовану Мішелем Фуко ідею, яка з'явиться щойно в другій половині XX ст. — теорія 
біополітики як контролю держави за тілами своїх громадян. 3 відчаєм через розлуку з коханим Марта ще може впоратися, оскільки ситуація мобілізації все-таки вписується в рамки зрозумілого їй світу, що тримається на суспільному договорі - чіткому розмежуванні сфер приватного і публічного. Війна гранично звужує цей приватний простір, оскільки тепер навіть тіло людини їй не належить. Проте інституалізований нав'язаний контроль держави у сфері міжособистісної комунікації зовсім цей приватний простір руйнує. Найбільшим ударом для протагоністки оповідання виявляється саме руйнування свого простору, знищення межі між приватним і публічним. 3 огляду на це, написану 1914-1915 року новелу можна навіть вважати передчуттям порушених Орвеллом у 1984 проблем. Де та межа, що відділяє державну доцільність і захист безпеки громадян від тотального поліцейського контролю над сферою приватного? Чи не є ситуації підвищеної небезпеки (війна, терористичні атаки, пандемія тощо) тільки приводом для впровадження чи збільшення такого контролю? Тим, що ставить приватне в центр уваги, Н. Кобринська проблематизує не тільки ці питання, а й окреслення сфери жіночого простору. Витіснена зі сфери публічного, увільнена від прийняття рішень, об'єктивізована жінка позбувається недоторканності навіть у тій царині, до якої було силоміць звужене ії життя. Власне, на зміну ракурсу, з урахуванням ідеологічної складової у прозі Н. Кобринської, звертає увагу Соломія Павличко - жіноча доля тут зображена ,з погляду інтелігентної, освіченої жінки 3 середнього класу (дочки священика або чиновника), котра усвідомила всю залежність і несправедливість власного становища" [Павличко 2002: 124].

Іще одна тема, якої торкається в новелі Свічка горить Н. Кобринська, це естетизація війни та ідеологічність мистецтва. Власне, саме така постановка проблеми теж $€$ вельми сучасною. Перед отриманням страшної звістки закохані грають увертюру до Вільгельма Телля: Мов бачаться мальовничі могутні альпійські гори, чується воєнний грізний дух, скрегіт збруї, мужеську силу, відвагу й тихі зворушеня серия [Кобринська 1990: 307]. Героїка, суспільне піднесення, подібність війни до стихії, але стихії не жахливої, а прекрасної (статичні у своїй величі гори, а не буря) — це ті естетизовані у музиці образи війни, які один по одному розбиватимуться для дівчини страшною дійсністю. Власне, новаторською тут є увага до персонажа, який не є носієм влади чи суб'єктом продукування ідеології, але тим, хто цю ідеологію відтворює через підтримання циркуляції певних дискурсів. Проте в Л. Альтюссера суб'єкт є продуктом ідеології, а в оповіданні Н. Кобринської суб'єкт якщо не дії, то принаймні рефлексії здатен зафіксувати у своїй свідомості переломний момент, коли усвідомлення різниці, нетотожності може перерости в опір. Цю різницю Н. Кобринська теж передає за допомогою музичних образів: Tuxi, мольові тонаиії, повні смутку, немочі, безсильної розпуки, переходили і змінялись в тверді, мужеські, енергійні звуки, щораз ближчі, голосніші [Кобринська 
1990: 307]. Звертаючи увагу на гендерно зумовлені психологічні нюанси новели, Алла Швець відзначає „егоїстичну імпульсивність дівчини” і „стоїчний чоловічий спокій” [Швець 2018: 668]. Проте, на нашу думку, ідеться радше про пов'язані зі сферою жіночого, приватного мінорні звуки, безсилля і відчай - 3 одного боку, й належні до царини чоловічого, публічного мажорні мелодії, влада і енергія - 3 другого. Домінування публічного-чоловічого глушить і витісняє жіноче-приватне, аж доки мінор зрештою не перетворюється на мовчання. І це теж дуже символічно — відсутність у публічному просторі наративів, пов'язаних із жіночим досвідом війни, має причиною не тільки монологічність чоловічого, а й мовчання жіночого. Натомість Н. Кобринська цей досвід озвучує, окреслюючи ще одну проблему - нерозробленість в публічному дискурсі належної мови для проговорення приватного жіночого досвіду в часи війни. Адже ця мова неминуче муситиме заходити в суперечність 3 домінуючими ідеологічними дискурсами, що й показує Н. Кобринська на прикладі подальшого розгортання подій у новелі Свічка горить. У цьому сенсі уважніше прочитання і переосмислення прози Н. Кобринської не останньою чергою резонує з нинішньою увагою до усної історії, пов'язаної 3 жіночим досвідом виживання і боротьби в часі війни, а також осмислення цього досвіду в художніх текстах.

У своїй увазі до витіснених, маргіналізованих наративів і досвідів Н. Кобринська навдивовижу послідовна і концептуальна. У фокусі іiї прози - icторії не тільки жінок, а й дітей, і навіть тварин. Важливим тут $є$ поділ на дике і свійське - свійські тварини втягнені в орбіту культури, а не природи, тому стають суб'єктами прийняття рішень: так, кінь з однойменної новели біжить до своїх після загибелі господаря, аби не втрапити в полон. Зображення тварини як людини не тільки релятивізує межу між тваринним і людським в ситуації війни (натура проти культури), а й загострює увагу на суб' єктності тварини - теж навдивовижу актуально з огляду на виникнення в останній третині двадцятого століття екоетики та рухів за права тварин. Ліс після битви — це не тільки понівечені людські тіла й калюжі крові: Поламані дерева лежали одні на других. На однім корчі перехилилася вбита серна, з відкритими скляними очима, а на півзламаній галузі висіла зачіплена одним крилом, поцілена в лету ворона [Кобринська 1990: 303]. Як зазначає Алла Швець, „антропоморфна семантизація душевного стану природи, конання лісу підсилюють трагедію загальнолюдського катаклізму” [Швець 2018: 675]. “Чужими” у воєнних новелах Н. Кобринської є персоналізовані й неперсоналізовані суб'єкти влади й ідеології, натомість “свої” — завжди жертви, причому як цивільні, так і військові, як люди, так і тварини.

У новелі Полищений дівчинка-підліток Магдуня рятує полишеного своїми пораненого жовніра, щоб потім втратити його в наступній битві: За якийсь час повідомив вдруге, що призначений до бою, $i$ від того часу Магдуня не 
мала від нього ніякої вістки [Кобринська 1990: 305]. Ця історія — не лише про втрати і жертви війни, а й про досвід символічного материнства, що його зазнає Магдуня в процесі дорослішання. Рятуючи жовніра від смерті, дівчинка в буквальному сенсі дає йому шанс другого народження, але дар виявляється змарнованим. Жіноче тут - те, що народжує і оберігає: на міфологічному рівні це значення зафіксоване в образі землі, що накриває живого, ховаючи його від смерті, адже Магдуня знаходить пораненого під купою викинутої 3 вирви глини. Цією ініціацією ніби передчувається досвід материнства реального - жовнір тут подібний до дитини, а Магдуня бере на себе материнські функції. Недарма врятований, на відміну від рятівниці, навіть не має іменівід самого початку він $€$ несамостійним не тільки через фізичну безпомічність внаслідок поранення, а й через те, що не має влади над своїм життям і не розпоряджається своєю долею. Його життя, як і його смерть - це наслідок рішень інших людей.

Не менш безпомічним почувається і красень Лукин із оповідання Калі$\kappa a-$ найбільш йому дошкуляє не так навіть втрата ноги, як страшні шрами на обличчі. Війна руйнує не тільки його тіло, родину (гине його дружина Маланка), “свій” простір (Хата була зовсім пуста - ні живої душі [Кобринська 1990: 333]), а й образ себе (Він глянув в блискучу покривку й замертвів. Одно око було менше, губа розтята, а ціле личе викривлене [Кобринська 1990: 332]). Що цікаво, описуючи Лукинові воєнні будні, Н. Кобринська акцентує його більшу зосередженість на власних відчуттях і спогадах, а не на зовнішніх подіях: Інші жалувались то на їу, то на те, щяо зле спати, - єму то було все одно, єго думки не були при нім, — він їх лишив за собою, біля своєї хати, загороди, жінки, дітей [Кобринська 1990: 328]. Лукин почувається чужим у війську, попри те, що в його частині було багато людей з його села. Свій простір для нього звужено до тіла — це не військо, частиною якого він $\epsilon$, і не держава, за яку треба воювати, а приватний простір спогадів. На думку Алли Швець, „мобілізаційна кампанія і новий військовий статус породжують трагічну психологію «відчуження» Лукина, усвідомленого переходу в інший буттєвий (танатологічний) простір війни" [Швець 2018: 672]. Симптоматично, що для Маланки лінія поділу між своїм і чужим не географічна чи національна, а передусім моральна: Та ще коби не рабували. Часом трапилися люди, щзо бесіду їх можна було порозуміти, та ще до свосї̈̈и запрошали, але були такі, що все з горшків повиїдали. Раз прийшли та иілий оборіг сіна забрали. Що наплакалася, напросилася, а вони ще й насміхалися [Кобринська 1990: 324]. Мародери ворожої армії в окресленому моральними координатами світі для Маланки $є$ не менш чужими, ніж жінки, “які забули, що їх чоловіки на війні, що їх кров проливають, та робили таку позну, що хрань господи” [Кобринська 1990: 324].

У нарисі На цвинтарі вододіл між своїм і чужим теж проходить в царині моралі - бездушна офіційна церемонія над пам'ятником загиблих нагадує 
ярмарок марнославства і протистоїть церковній відправі, що в ній скорбота за полеглими дістає найбільш адекватне вираження: Господи, господи помилуй! - дрожав голос старого священика, а народна душа плакала над своїм тяжским горем [Кобринська 1990: 314]. Адже досі увага присутніх була зосереджена на молодому поручникові, що зваблював дівчат і молодиць, а тепер мав одружитися “з проворною панночкою” [Кобринська 1990: 312], яка перемогла всіх суперниць. На не меншу увагу здобувся “гарний з вигляду” хорунжий, творець пам'ятника, хоча й він зовсім не перейнятий скорботою моменту: Сго погляд переходив від пам'ятника на публіку, як би слідив за вражінем, яке робив на ню пам'ятник [Кобринська 1990: 313]. Він час від часу поглядає на молоду дівчину, яка стала моделлю для постаті Валькірії, а вона, натомість, споглядає відображені в камені обриси власного обличчя. Ці погляди, натяки, мова тіла і перешіптування формують сітку взаємин, якою зв'язані військові з цивільними. Пам'ятник тут - ніщо інше, як точка, навколо якої формується ця горизонтальна сітка соціальної взаємодії. Натомість в окресленому письменницею просторі існує ще й інший вимір, вертикальний, яким живі з'єднані з полеглими. Недарма церковний спів, який є наочним втіленням скорботи, лунає “гейби з-під землі” [Кобринська 1990: 313], а земля “стоном відповідала: «Буду їм пером»” [Кобринська 1990: 314]. Проте публіка, найбільшим бажанням якої є швидко розійтися, залишається страшенно невдоволена появою процесії.

Наталя Кобринська, зіштовхуючи у своїй прозі традицію і модерність, зображує українську спільноту в момент розпаду звичних і прокреслення нових зв'язків. Ідентичність, що доти була справою належності, стає питанням вибору. У цьому сенсі Яким Мачук, який між соціальною і національною ідентичністю обирає останню, в дечому дивно подібний до Галі з повісті Задля кусника хліба, ідентичність якої теж є результатом свідомого вибору - попри те, що іiі реальна соціальна позиція не узгоджується зі сліпою вірою у власні ілюзії. Персонажі воєнних новел Кобринської з такою само неочевидністю визначають своїх і чужих, керуючись моральними принципами. У художній прозі Наталі Кобринської відбувається переосмислення категорій публічного і приватного, а також традиції героїзації, характерної для воєнних наративів.

\section{Список використаної літератури}

Ashcroft B., Griffiths G. \& Tiffin H., Post-colonial studies: the key concepts, New York: Routledge, 2007.

Bauman Z., Identity: Conversations with Benedetto Vecchi, Cambridge: Polity Press, 2004.

Donskis L., Troubled Identity and the Modern World, New York: Palgrave Macmillan, 2009. 
Hall S., The question of cultural identity, [in:] S. Hall, D. Held, A. McGrew, Modernity and its futures, Cambridge: Polity Press in association with the Open University, 1992, p. 274-316.

Smith A.D., The Cultural Foundations of Nations: Hierarchy, Covenant and Republic, Oxford: Blackwell Publishing, 2008.

Агеєва В., Жіночий простір: Феміністичний дискурс украӥнського модернізму, Київ: Факт, 2003.

Книш І., Смолоскип у темряві. Наталія Кобринська й украӥнський жіночий рух, Вінніпег: Новий шлях, 1957.

Легкий М., Проза Наталії Кобринської (ідейно-естетична еволюиія й поетика), [в:] „Українське літературознавство”, 2012, вип. 75, с. 95-115.

Новикова М., Прасвіт українських замовлянь, [в:] Украӥнські замовляння, Київ: Дніпро, 1993, c. 7-32.

Павличко С., Наталя Кобринська в контексті епохи, [в:] Павличко С., Фемінізм, Київ: Вид-во Соломії Павличко „Основи”, 2002, с. 121-127.

Швець А., Жінка з хистом Аріадни: Життєвий світ Наталї Кобринської в генерачійному, світоглядному та творчому вимірах, Ін-т Івана Франка НАН України, Лекторій СУА з жіночих студій, ВГО Союз Українок, Львів, 2018.

\section{Список використаних джерел}

Кобринська Н., Вибрані твори, Київ: Дніпро, 1980.

Кобринська Н., Дух часу. Оповідання, повість, Львів: Каменяр, 1990.

\section{Spysok vykorystanoi literatury \\ [References]}

Aheieva V., Zhinochyi prostir: Feministychnyi dyskurs ukrainskoho modernizmu [Women's Space. The Feminist Discourse of Ukrainian Modernism], Kyiv: Fakt, 2003.

Knysh I., Smoloskyp u temriavi. Nataliia Kobrynska y ukrainskyi zhinochyi rukh [A Torch in the Darkness. The Work of Natalia Kobrynska, Founder and Leader of the Ukrainian Women's Movement], Winnipeg: Novyi shliakh, 1957.

Lehkyi M., Proza Natalii Kobrynskoi (ideino-estetychna evoliutsiia y poetyka [Natalia Kobrynska's Prose (Ideological-Aesthetical Evolution and Poetics)], [v:] „Ukrainske literaturoznavstvo", 2012, vyp. 75, s. 95-115.

Novykova M., Prasvit ukrainskykh zamovlian [The Ancient World of Ukrainian Spells], [v:] Ukrainski zamovliannia [The Ukrainian Spells], Kyiv: Dnipro, 1993, s. 7-32.

Pavlychko S., Natalia Kobrynska v konteksti epokhy [Natalia Kobrynska in the Context of the Epoche], [v:] Pavlychko S., Feminism, Kyiv: Vyd-vo Solomii Pavlychko „Osnovy”, 2002, s. $121-127$.

Shvets A., Zhinka z khystom Ariadny: Zhyttievyi svit Natalii Kobrynskoi v heneratsiinomu, svitohliadnomu ta tvorchomu vymirakh [A Woman with Ariadne's Gift: The Life Path of 
Nataliia Kobrynska in Generational, Worldview, and Creative Dimensions], In-t Ivana Franka NAN Ukrainy, Lektorii SUA z zhinochykh studii, VHO Soiuz Ukrainok, Lviv, 2018.

\section{Spysok vykorystanykh dzherel \\ [References]}

Kobrynska N., Vybrani tvory [The Collected Writings], Kyiv: Dnipro, 1980.

Kobrynska N., Dukh chasu. Opovidannia, povist [The Spirit of the Times. Short Stories, Novel], Lviv: Kameniar, 1990. 